\title{
The Contribution of Emotional Intelligence and Interpersonal Communica- tion on Teacher Performance Through Job Satisfaction
}

\author{
Adny Novita Sari *, Sulaiman, Ahmad Suriansyah \\ Master Program of Education Management Universitas Lambung Mangkurat Banjarmasin 70123 \\ Indonesia
}

Article history:

Submission November 2019

Revised May 2020

Accepted May 2020

${ }^{*}$ Corresponding author:

E-mail: adnynovitasari@gmail.com

\begin{abstract}
This study aims to analyze the contribution of emotional intelligence and interpersonal communication to teacher performance through teacher job satisfaction. This research uses quantitative descriptive methods. A sample of 194 people from 377 teachers spread across 13 high schools in Banjarmasin. Data were extracted using a questionnaire that has been valid and reliable and analyzed using Path Analysis. The results showed that: (1) There was a direct contribution between emotional intelligence, interpersonal communication, job satisfaction, and teacher performance (2) There was an indirect contribution between emotional intelligence, interpersonal communication through job satisfaction as an intermediary variable on the performance of teachers at the SMAN Banjarmasin City. This study concludes that significant results are obtained for all variables studied.
\end{abstract}

Keywords: Emosional intelligence, interpersonal communication, job statisfaction, teacher performance

\section{Introduction}

Therefore, every school always wants to improve the performance of educators in achieving the school goals that have been determined. Performance is explained as a level of achievement of the results of the tasks that have been carried out (Simanjuntak, 2005).

In connection with this, Goleman (2016) states emotional intelligence also has an important role in the success and performance of a person because actuality alone cannot work as well as possible without emotional intelligence. Emotional intelligence influences the development of teacher performance.

Communication is an activity that is always done by everyone because communication is one of the needs of humans as social beings. Performance Effective communication can give effect to one's performance because communication provides a channel for the management process in providing information and building understanding (Suriansyah, 2014). This is made clear by the results of a study conducted by Fathurahman (2010) which concluded that there was a strong and positive relationship between communication with the morale and performance of elementary and junior high school teachers.

Suriansyah (2018) in his study states that teacher job satisfaction has a significant impact on the quality and productivity of teacher work to realize national education goals.

Robbins (2012) argues that someone with a high level of job satisfaction has positive feelings about the job, while someone dissatisfied has negative feelings about his job. So it can be said that someone who has a sense of satisfaction with his work tends to perform better. Job satisfaction according to Gibson in

\section{How to cite:}

Sari, A. N., Sulaiman., \& Suriansyah, A. (2019). The contribution of emotional intelligence and interpersonal communication on teacher performance through job satisfaction. Journal of K6, Education, and Management, 2 (3), 229 - 233. doi: 10.11594/jk6em.02.03.07 
Winardi (2008) is part of the motivation process. Employees can feel satisfied or not, always related to the performance and results of their work. Therefore, the level of job satisfaction in an organization can usually be attributed to results such as employee attitudes, employee turnover, absenteeism, tardiness, and complaints that are common in an organization.

Syamsudin (2006) provides an understanding of performance as the level of execution of tasks that can be achieved by someone using existing capabilities and boundaries set to achieve organizational goals. According to Goleman (2000), every individual in an organization that has good emotions tends to have the will to improve and improve its performance.

In addition, Edwardin (2006) also states that emotionally intelligent teachers can understand how emotions occur, can regulate their emotions, reduce unproductive emotions that become obstacles in cooperation, and can establish a harmonious social life with fellow teachers, the community around the work environment and the community where they live.
In addition to emotional intelligence, other factors that contribute to performance are communication which is the main factor in improving work quality, because a job is inseparable from the adequacy and accuracy of information about work, attention to the needs of workers, complaints, and opportunities to interact intensively vertically and horizontally, which in the end it fosters both happy and unhappy feelings when working on a job (Suriansyah, 2014).

\section{Material and Methods}

The population of the study was 377 people at the Banjarmasin Senior High School. The research sample was 194 teachers in 13 schools selected by proportional stratified random sampling. Data was collected using a five-scale model questionnaire that was tested for validity and reliability by choosing between one to five answers that best fit the actual conditions. There are four questionnaires used in this study namely emotional intelligence questionnaire, interpersonal communication questionnaire, job satisfaction questionnaire, and teacher performance questionnaire. Following the conceptual relationship model between variables as shown in Figure 1.

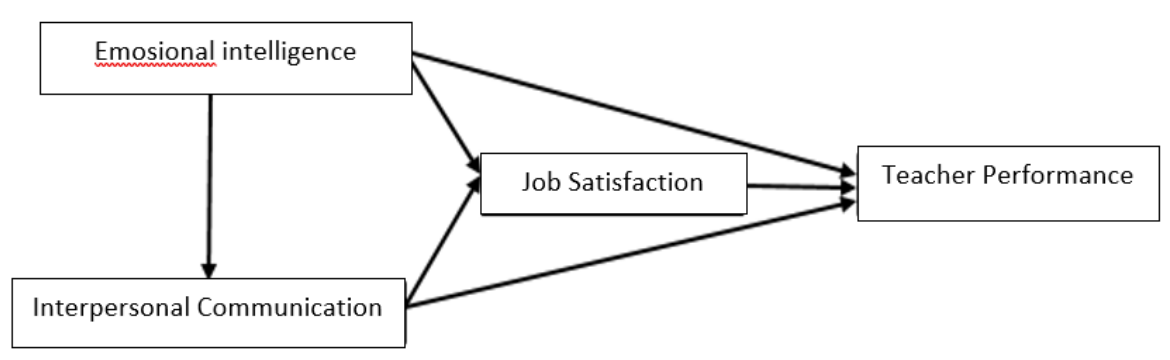

Figure 1. Research model

\section{Results and Discussion}

The results of respondents' descriptive statistical analysis of the research variables, namely emotional intelligence, interpersonal communication, job satisfaction, and teacher performance measured on a scale of 5 are shown in Table 1 which includes the mean, standard deviation, and categories.

Descriptive data in Table 1 gives the meaning that the respondent gives the highest emphasis in answering the research questionnaire on job satisfaction and the lowest emphasis is emotional intelligence.

The results of the classical assumptions test include residual normality data tests using the Kolmogorov-Smirnov one-sample method showing all the variables are normally distributed.

Homogeneity test results indicate that all variables used are from the same population or 
homogeneous variance. The results of the multicollinearity test showed the tolerance value of each variable was more than 0.1 and the VIF value was more than 10 . Besides, heteroskedasticity test results on all variables showed a significance value of more than 0.05 .
The results of testing the analysis requirements have been met, the next step is the interpretation of the results of the path analysis with a summary of the results in Table 2.

Table 1. Mean, standard deviation, and categories of research variables (SPSS 19)

\begin{tabular}{lccc}
\hline \multirow{2}{*}{ Variable } & \multicolumn{3}{c}{ Descriptive } \\
\cline { 2 - 4 } & Mean & Standard Deviation & Category \\
\hline Emotional Intelligence & 100,29 & 11,754 & Medium \\
\hline $\begin{array}{l}\text { Interpersonal } \\
\text { Communication }\end{array}$ & 106,64 & 4,617 & Very high \\
\hline Job satisfaction & 164,86 & 6,090 & High \\
\hline Teacher Performance & 50,66 & 2,835 & Very high \\
\hline
\end{tabular}

Table 2. Results of Path Analysis in Structure Model 1

\begin{tabular}{|c|c|c|c|c|c|c|}
\hline \multicolumn{7}{|c|}{ Structural 1 Emotional Intelligence for Interpersonal Communication } \\
\hline Variable & $\begin{array}{c}\text { Path coeffi- } \\
\text { cient }\end{array}$ & $\boldsymbol{t}$ & Sig & $R^{2}$ & $\boldsymbol{F}$ & Sig \\
\hline $\begin{array}{l}\text { Emotional } \\
\text { Intelligence }\end{array}$ & 0,515 & 2,204 & 0,029 & 0,025 & 4,858 & 0,029 \\
\hline
\end{tabular}

Table 3. Results of path analysis in structure model 2

\begin{tabular}{|c|c|c|c|c|c|c|}
\hline \multicolumn{7}{|c|}{ Structural 2 Emotional Intelligence, Interpersonal Communication on Job Satisfaction } \\
\hline Variable & $\begin{array}{c}\text { Path coeffi- } \\
\text { cient }\end{array}$ & $t$ & Sig & $R^{2}$ & $\boldsymbol{F}$ & Sig \\
\hline $\begin{array}{l}\text { Emotional } \\
\text { Intelligence }\end{array}$ & 0,142 & 2,003 & 0,047 & \multirow{2}{*}{0,059} & \multirow{2}{*}{6,000} & \multirow{2}{*}{0,003} \\
\hline $\begin{array}{l}\text { Interpersonal } \\
\text { Communication }\end{array}$ & $-0,222$ & $-3,115$ & 0,002 & & & \\
\hline
\end{tabular}

Table 4. Results of path analysis in structure model 3

\begin{tabular}{|c|c|c|c|c|c|c|}
\hline \multicolumn{7}{|c|}{$\begin{array}{c}\text { Structural } 3 \text { Emotional Intelligence, Interpersonal Communication, Job Satisfaction of Teacher } \\
\text { Performance }\end{array}$} \\
\hline Variable & $\begin{array}{l}\text { Path coeffi- } \\
\text { cient }\end{array}$ & $t$ & Sig & $R^{2}$ & $\boldsymbol{F}$ & Sig \\
\hline $\begin{array}{l}\text { Emotional } \\
\text { Intelligence }\end{array}$ & 0,142 & 2,003 & 0,047 & \multirow{2}{*}{0,059} & \multirow{2}{*}{6,000} & \multirow{2}{*}{0,003} \\
\hline $\begin{array}{l}\text { Interpersonal } \\
\text { Communication }\end{array}$ & $-0,222$ & $-3,115$ & 0,002 & & & \\
\hline
\end{tabular}

Table 5. Summary of decisions on hypothesis testing H1, H2, H3, H4, H5, and H6

\begin{tabular}{lll}
\hline Hypotesis & $\boldsymbol{p}$ & Decision \\
\hline $\begin{array}{l}\text { There is a direct contribution of emotional intelligence to } \\
\text { teacher performance }\end{array}$ & 0,048 & Accepted \\
$\begin{array}{l}\text { There is a direct contribution of interpersonal communication } \\
\text { to teacher performance }\end{array}$ & 0,034 & Accepted \\
\hline Continue to... & & \\
\hline
\end{tabular}




\begin{tabular}{lcc}
\hline Hypotesis & $\boldsymbol{p}$ & Decision \\
\hline $\begin{array}{l}\text { There is a direct contribution of emotional intelligence to job } \\
\text { satisfaction }\end{array}$ & 0,015 & Accepted \\
\hline $\begin{array}{l}\text { There is a direct contribution of interpersonal communication } \\
\text { to job satisfaction }\end{array}$ & 0,006 & Accepted \\
\hline $\begin{array}{l}\text { There is a direct contribution of job satisfaction to teacher } \\
\text { performance }\end{array}$ & 0,023 & Accepted \\
$\begin{array}{l}\text { There is a direct contribution of emotional intelligence to } \\
\text { interpersonal communication }\end{array}$ & 0,029 & Accepted \\
\hline
\end{tabular}

The results of path analysis as shown in Table 2, Table 3, and Table 4 are used to answer ten research hypotheses that have been formulated and the decision of the analysis results can be seen in Table 5 and Table 6. Table 5 is a summary of the decision of hypothesis 1 through hypothesis 6 with a critical value of less than 0.05 , then the hypothesis is accepted. Table 6 is a summary of the decision of testing hypothesis 7 to hypothesis 10 which is an indirect contribution.

Emotional intelligence is the ability to control negative things or the ability to focus attention on positive things such as selfconfidence and harmony with people around (Goleman, 2016). This finding is in line with research conducted by Mulyani (2008) about the influence of emotional intelligence factors on the ability that emotional intelligence influences communication skills. Besides, research conducted by Novia Adhityas also states that there is a positive and significant relationship between emotional intelligence on interpersonal communication. Therefore, we cannot avoid communicating with others. If emotional intelligence affects interpersonal communication, teachers who do not have high emotional intelligence will influence increased interaction and relationships in the school environment and outside the school.

According to Ginanjar (2010), emotional intelligence is the ability to feel. The key to emotional intelligence is the honesty of conscience. That conscience should be the center of principles that can provide security, guidance, strength, and wisdom. When this is carried out in a work environment, it results in improved performance and achieving success.

Besides, Retno also stated that there was a positive and significant influence between emotional intelligence on teacher performance. Hidayat suggests that emotional intelligence has a significant effect on performance. Emotional intelligence has a function by knowing when and how to express emotions so that it can be a control for each individual in carrying out activities and demands of work in an organization. Research by Wihyanti (2015) also explains that there is a positive and significant relationship between emotional intelligence on teacher performance.

The research conducted by Suriansyah (2014) also supports the finding that there is a positive and significant relationship between interpersonal communication on teacher performance. A teacher who has good performance usually has low interpersonal communication due to the professional attitude they have. It does not require a lot of interaction and social relationships to be able to improve its performance.

Findings in research on job satisfaction can make a positive contribution to teacher performance supported by statements made by Sirohi and Shivastva that job satisfaction affects the performance where job satisfaction increases, performance will also increase. Besides, research by Werang shows that teacher job satisfaction significantly influences teacher performance. The link between performance and teacher job satisfaction can be seen from the opinion raised by Hanif that teacher performance is significantly influenced by various factors, one of which is job satisfaction. Besides Hidayat also proved from the research he did that emotional intelligence has a significant contribution to job satisfaction. Another study by Fauzi found that emotional intelligence has a positive effect on teacher job satisfaction. Amir states that good 
interpersonal communication has a positive impact on the amount of job satisfaction.

The results of this study are supported by Sukmawati which states that positively and significantly both simultaneous and partial emotional intelligence and job satisfaction affect performance.

The results of this study are in line with Ramdani which states that there is an indirect addition of the construct of job satisfaction in strengthening the effect of interpersonal communication on performance. Goleman (2005) revealed that emotional intelligence consists of five main dimensions, namely recognizing one's emotions, managing emotions, motivating yourself, recognizing the emotions of others, and building relationships. Interpersonal communication will help to establish relationships/interactions with other people so that it raises a sense of empathy. In line with the research of Nair et al. which states that important emotional intelligence is owned by employees of an organization, because it will affect their job satisfaction, job satisfaction of others, and organizational effectiveness.

\section{Conclusion and Recommendation}

The conclusions of the results of the research contribution of emotional intelligence and interpersonal communication to teacher performance through high school job satisfaction in Banjarmasin city is a significant result for each variable in all hypotheses.

It is recommended that teachers and principals in SMAN City in Banjarmasin and the Head of the Office of Education and Culture of South Kalimantan Province be able to help and maintain emotional intelligence, interpersonal communication, job satisfaction, and performance values by providing suggestions and solutions to problems faced by teachers, inviting teachers to rectify the situation that is not good through cooperation and tolerance. It is recommended to other researchers to conduct research similar to this study by raising the same variable in different places and can use this research as literature and information source to conduct further research in the field of education.

\section{Acknowledgment}

Our gratitude and appreciation extend to all parties involved and contributed in completing this research.

\section{References}

Edwardin, L. T. (2006). Analisis Kompetensi Komunikasi, Kecerdasan Emosional, dan Budaya Organisasi terhadap Kinerja Karyawan (Studi pada PT POS Indonesia (Persero) se Kota Semarang). Program Pascasarjana Universitas Diponegoro Semarang.

Fathurahman. (2010). Hubungan Komunikasi dan Semangat Kerja dengan Kinerja Guru SD-SMP di Kabupaten Balangan. Tesis Magister Manajemen Pendidikan.

Ginanjar, A. (2010). Kecerdasan Emosi dan Spiritual. Jakarta: Arga.

Goleman, D. (2000). Working With Emotional Intelligence: Kecerdasan Emosi Untuk Mencapai Puncak Prestasi. Jakarta: PT Gramedia Pustaka Utama.

Goleman, D. (2016). Emotional Intelligence. Jakarta: PT Gramedia. Mulyani, S. (2008). Analisis Pengaruh Kecerdasan Emosional Terhadap Komunikasi Interpersonal Perawat dengan Pasien di Unit Rawat Inap RSJD DR. Amino Gondohutomo Diponegoro. Semarang.

Robbins, S. (2012). Perilaku Organisasi. Jakarta: Salemba Empat. Simanjuntak, P. J. (2005). Manajemen dan Evaluasi Kerja. Jakarta: Lembaga Penerbit Fakultas Ekonomi UI.

Suriansyah, A. (2014). Hubungan Budaya Sekolah, Komunikasi, dan Komitmen Kerja Terhadap Guru Sekolah Dasar Negeri. Jurnal Cakrawala Pendidikan.

Suriansyah, A. (2018). Kepuasan Kerja Guru Di Sekolah Dasar: Hubungan Dengan Lingkungan Belajar. The Open Psychology Journal, 2(1), 1-9.

Syamsudin. (2006). Manajemen Sumber Daya Manusia. Bandung: Pustaka Setia.

Wihyanti, R. (2015). Pengaruh Kecerdasan Emosional Terhadap Kinerja Guru Bersertifikat Pendidik di Sekolah Dasar Kecamatan Tegal Barat Kota Tegal . Skripsi Universitas Negeri Malang.

Winardi.(2018). Pemotivasian dalam manajemen. Jakarta: PT. Rajagrafindo Persada. 